\title{
INTERVIEW WITH HUNGARIAN FOLKLORIST AND ETHNOLOGIST MIHÁLY HOPPÁL ON THE OCCASION OF HIS 70TH JUBILEE
}

\section{Interviewer Nikolay Kuznetsov}

\section{Could you please say a few words about your origin?}

I was born in a small town called Kassa (Košice), which today belongs to eastern Slovakia. I usually say that I come from a middle-class family - that of a railway clerk. It was fortunate for me as people with middle-class background considered learning essential.

In 1955 we moved to Sárospatak, a town with a high-level gymnasium. I was lucky to attend it. The school had been established 400 years ago and it was well-known all over Hungary. It was one of the best gymnasiums in the country. At the time I attended it, it could boast many teachers from the old staff. In addition to good teachers, the school in Sárospatak had an excellent library. I took to it from the very beginning. I liked the smell of the books there.

I remember well that, as a schoolboy, I wrote a small research entitled Sárospataki diákok a '48-as forradalomban (Sárospatak students in the 1848 revolution). Many students from Sárospatak joined the fight for freedom. I just loved it: what an elated idea - freedom!

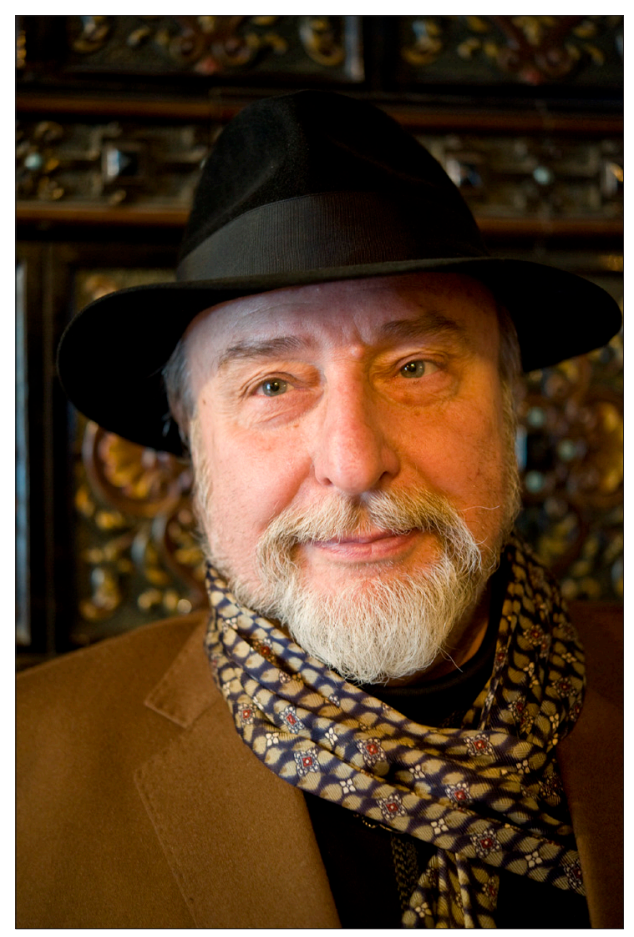

Mihály Hoppál. 
In addition, Sárospatak is the home town of Hungarian freedom-fighter Ferenc Rákóczi. In Sárospatak we lived across the Rákóczi Castle and, as children, played in the castle gardens. My father was a doctor, a gynaecologist.

Later on, during my university years, I visited the neighbourhood to collect my first ethnographic materials on folk medicine in Zemplén County.

\section{Did you enter university right after finishing gymnasium studies?}

No, I skipped a year. At that time universities did not willingly accept those with no working class background. So after high school I worked on the railway for a year and gained extra points for entrance the next year. Times were like that.

\section{Did you undertake ethnology studies from the very beginning?}

Yes, I majored in the Hungarian language, literature and ethnology from the very start.

My father was friends with the director of the museum that was housed in Rákóczi Castle. And this was a reason why I took to ethnology. I was not particularly eager to become a historian; yet, I was considering majoring in history. This museum director was an ethnographer, my father's good friend, and then I decided that I was into it.

\section{What is it that interests you most in ethnography?}

I started with research into folk medicine. My first book entitled Népi gyógyitás Magyarországon (Folk Medicine in Hungary) is dedicated to this topic, and the book has also been published in English. My diploma thesis Zempléni népi gyógyítás (Zemplén Folk Medicine) - about 200 pages of research on the material I collected myself - dealt with the same subject matter.

This was the time when an ethnography research group was established at the Hungarian Academy of Sciences. It was led by Gyula Ortutay, and he hired me right away. The year was 1967, so I have been working there for 45 years already.

The ethnography research group was in need of younger researchers, as most of the members already had doctoral degrees. They had a voluminous collection that had to be put into order. And so Éva Pócs and I systematised it by illnesses, medicinal herbs, healing methods, places, etc. In the course of this work I came to understand many things: for example, how folk beliefs work. Folk medicine is a mixture of knowledge and beliefs. And so I engaged myself in the system of beliefs. 


\section{How did you come to study shamanism?}

In 1972, Vilmos Diószegi, Head of the Department of Folklore, left the academy, leaving behind an English-language manuscript that I was supposed to edit. This work resulted in a book entitled Shamanism in Siberia. This was how I delved into exploring shamanism.

\section{You are also known as an ethno-semiotician...}

In 1967, I happened to be in Moscow for the first time, participating in a course at the Institute of Slavonic and Balkan Studies. I stayed there for three months. Each week somebody presented a paper, and finally my turn came. My presentation topic was Notes about Ethno-Semiotics. In Moscow I also had a chance to meet Vyacheslav Ivanov, Valery Toporov, Yuri Lotman and other prominent figures from the Moscow school of semiotics.

From Moscow I took with me volumes of Sign Systems Studies. I also read a paper on this subject at the University of Budapest. Then, together with Vilmos Voigt, we devised ethno-semiotics, which is description of ethnographic phenomena with the methods of semiotics.

And then I met Valery Basilov. He was Research Secretary at the institute in Moscow, while I had the same position at the Institute of Ethnography in Budapest. And we became friends. He also studied shamanism. Then I went to Moscow for the second time, now already for half a year period.

\section{Could we regard these Moscow researchers as your greatest mentors?}

Yes, you could. I learned the most from my Moscow colleagues. They sent me offprints to read. We once also went to the basement where the film collection was stored. They showed it to me but I was asked to keep it a secret. The collection included primary material, video footages from Simchenko and Oskin, which were made into films only decades later. I concluded that, as shamans had been filmed, they still existed. And that it would be interesting to go and see them. Local colleagues told me that I could try.

I considered going to the Kyrgys in Central Asia, and also to the Caucasus, as I wanted to explore the Turkic peoples. There I befriended Georgian scientists and an Armenian, Sarkis Arutjunjan, who has written about Armenian mythology. In short, I was trying to find my place in life. And I was greatly influenced by the fact that I was able to participate in fieldwork.

After that I tried to visit Moscow annually, bringing back the most recent scientific publications. By the way, I was the one to first publish Lotman's works in Hungarian. Moreover, this was Lotman's first publication abroad, i.e., 
outside the Soviet Union. When Lotman visited Hungary, he expressed deep gratitude to me for that. I took great pride in the fact that semiotics research was also published in Hungary.

I also started my trips to Italy, as Italians also developed an interest in semiotics. It was Umberto Eco who took it up. Before that, he used to be a linguist, not a real semiotician. Then he started writing The Name of the Rose. I remember that once, at the dinner table, he mentioned something about using a strange device that enabled moving the text back and forth (the computer).

At the time, they organised one- or two-month semiotics courses in Italy. I also got a scholarship for attendance, and delivered a lecture on research into mythology in the Soviet Union, introducing the ideas of Ivanov, Toporov, Lotman and some others. I regarded it as my special role - to be like a shaman, a mediator between the two worlds, East and West.

And then we had an idea that colleagues from the Soviet Union could come to Hungary and researchers from Europe were also allowed to come there already. So we decided to organise the first shamanism conference in Hungary, which was dedicated to the memory of Vilmos Diószegi. It took place in the beautiful town of Sárospatak. The conference was a real success, and resulted in the publication of Shamanism in Eurasia.

We also asked some Finns to participate: Juha Penttikäinen, Anna-Leena Siikala, etc. I also frequented Finland at the time. And once in Helsinki, when sitting in Juha's sauna (all important things are settled in sauna) we decided to start a series on Uralic mythologies in the form of a comparative encyclopaedia.

\section{You have travelled all over the world. Could you name a place that you would like to visit time and again?}

China is definitely one of these places. You can find many small nations there which have not been thoroughly investigated from the scientific point of view. However, the Chinese themselves have recently started to explore the cultures and ethnographies of their small nations; for instance, the ministry has ordered monographs on this topic. Also, there are young people among ethnic minorities who study to become ethnographers, folklorists, etc.

\section{Each small nation in Asia has their own language. Does it make things complicated for a researcher from Europe?}

Yes, it does. And I really regret that I was not able to learn all these languages. Yet, in order to do this, you have to get there at an early age. One of my colleagues, Dávid Somfai Kara, was just at the right age and was able to travel all over the Soviet Union. He went to Central Asia and learned a few local languages. I did not have a chance to do it and this is a severe shortcoming. 
However, I realised that everything that I saw could be recorded visually. And I was also lucky as this was when the rebirth of shamanism began. In China it happened a bit later, but I made it there in time as well. Foreigners had not been there much and I was allowed to do different things. My predecessor Diószegi, for example, had not been allowed to conduct research properly. So, I was also lucky, which you have to be in order to do your work fairly well. You have to be determined and enthusiastic, but it is also very important that you are at the right place at the right time.

After a conference in Budapest a Buryat researcher, who also participated in the conference, invited me to his country. He did not want to take me to fieldwork, either, but at least showed me materials at the museum. Even that was a big deal, as nobody else had been allowed to go there before me. Actually, in the beginning I was declined access as well; they said that the museum was under repairs. I said that this was the special purpose of my visit. Then my colleague promised to arrange it for me. So I was also able to take pictures there.

When I went to China, which I was not permitted to do in the beginning, either, I expressed a wish to explore smaller nations in the countryside regions as well. They told me it was not possible. I explained that I was not a tourist, that I had come for work purposes. It took great pains to get a permit to go to the Manchus' former capital Changchun. In conversations with my colleagues they mentioned that they had some shamanic items. I was so happy and thought that I could go to the museum and see the display and take pictures of the objects. But they brought the items to me in two suitcases. I did not say a word.

Some years later I learned that as I had behaved myself and had not expressed any anger, they had decided to take me to a shaman. This was my first live meeting with a real shaman. But before China I had visited Korea, where I bought a small camera that enabled taking quick snapshots. It was this camera that I used for taking pictures of this old shaman. So I was lucky again.

After my third journey to China they told me that they had taken me to the shaman because I had not been impatient and aggressive.

\section{Maybe, in addition to luck, a researcher should also possess certain per- sonality features?}

Definitely perception. With a person from the east you have to sit and talk lengthily, and maybe also drink some wine; you should not hurry. For them time runs its own course.

\section{Have you ever wanted to learn to become a shaman yourself?}

I have repeatedly been asked the same question during fieldwork. A Tuva shaman once said to me: you are my son. My answer was that I could not stay 
there and learn everything as I already had a family and my whole life back at home. A young single person can stay there for months, learn the language and other things.

I was in an advantaged position as I had edited publications on shamanism and read special literature, so I was able to ask relevant questions. It takes quite long for a young researcher to gain knowledge about all that as they lack all the basics. Especially English-speaking researchers are like that. Thanks to Diószeg I knew a lot of things beforehand: for example, when shooting a film, I knew exactly what to shoot, what to turn attention to, etc.

In Korea a female shaman also made a proposition to me to come and study under her supervision. She also had three really beautiful disciples, one betterlooking than the other. I would have loved to stay; yet, I had my flight ticket in my pocket with the exact return date on it.

As already said, this work has to be started when you are still young. And now, being seventy years old, I have to say that there are so many things that I would like to accomplish. Actually I do not need to travel any more, as I have a dozen of bulky volumes of fieldwork materials that I have collected, and also some additional materials that have not been even processed yet. On this basis several books could be written. This material should be elaborated and, in the course of this, all the questions that you also asked should be answered.

So my answer to your question if I have ever wanted to become a shaman is negative. These are two different occupations: you can be an ethnographer, anthropologist or ethnologist, or you can be a shaman. You should not blend these two together, especially if the local language is not your mother tongue. Mythology can be understood only in your mother tongue. This is why we made a decision long ago that Uralic mythologies should be written by local researchers. As for me, I should write Hungarian mythology. Fortunately, good things have been written also previously. Arnold Ipolyi's work is definitely among the best ones, and I have also re-published it. However, many things have to be written again, as old books have a very different structure, and so on.

\section{Why do we have to study shamanism?}

I could give two different answers to this question. On the one hand, we have to explore not only shamanism, but also other ingredients of culture, because all of them are essential: food, songs, dances, etc. On the other hand, shamanism has to be investigated and it is worth investigating even more, as in the 1990s and 2000s small nations were able to present part of their culture as a symbol of national identity. And these small nations could not boast many things to pick out for presenting, so shamanism was just 'the thing'. Also, this coincided with UNESCO's decision to protect and preserve folklore, so the time was 
favourable. They succeeded even in China. In the regions where shamanism survived (communist) persecution, this presented a good opportunity. And by today it is already business. Hero epics also emerged, for example, Manas by the Kyrgys people and Olonkho by the Yakuts.

\section{What would the world be like without shamanism and shamans?}

It is a good question, but we will never know. The healing technique that for the less cultured peoples starts with sound-making (clapping hands, tapping two sticks together) has proved to be very efficient. What is very important in shamanic healing is that many people come together and concentrate on the sick person. It is an ancient technique in which each person concentrates and directs their energy on the same spot. Modern medicine has nothing of the kind. This is human approach and could be learned from shamans.

People assemble, sing together, watch the shaman beat the drum; they are emotionally involved in the healing process, listen to the recommendations that the shaman gives to the family members kneeling in front of him, and participate in the joint party where the meat of the sacrificed animal is eaten. And it is important here that the shaman is the one who organises the community and its life. This has continued for thousands of years, and this is how religion has evolved.

We are increasingly arguing that already Neanderthals had shamans. It was shamans who gathered a few dozens of people around them to form communities. On this basis people developed a sense of belonging. Shamans also had their say in the preparations for hunting trips, performing rituals; they sang about the past, and repeatedly told stories to the community of who they were and where they came from. This way, shamans recreated identity and preserved the community's wisdom. In conclusion we could say that we would be worse off without them.

\section{You have written many books. How have shamans reacted to them?}

I have also taken my books to them, although it has often happened that by that time some older shamans have already passed away into the afterlife. Honestly speaking, I really do not know what their opinion is. I believe that they are not interested in my books; they live in a world of their own. Of course, today's shamans are happy to participate in TV-shows and so on. Yet, this is not important for proper shamans.

\section{Are there any shamans in Hungary?}

There are some neo-shamans. 


\section{And what do you think about neo-shamanism?}

I think that this is the result of natural evolution. Especially at the time when so-called empty spaces emerge everywhere, as there is no faith. This is a queer thing which, in a sense, could be called psychotherapy. Many people say that it is a good thing, so let it be - especially if it brings in money.

\section{What do you think of Finno-Ugric relationships, the so-called Ugric-Turkish} war, etc.?

I have never concealed the fact that I like Ago Künnap's theory. I am of the same opinion with him that we cannot deny the existing theory but we still have to re-analyse certain parts of it. Because, as he has also proved, things look different from a different angle. You do not need to or even must not be dogmatic. A real scientist is open to everything new and accepts the fact that someone else can prove that they are right. Angela Marcantonio argues that the ones referring to János Sajnovics have misunderstood the Latin text and this is where errors have started.

Recently a big etymological dictionary of old Turkish languages was completed. We cannot deny that certain words occur there. We are not able to explain Árpád, Álmos, táltos, or boszorkány from the Finno-Ugric point of view. And this is the place for contemplation. For instance, if god and similar concepts belong in Uralic mythology, then the word isten cannot be placed in the FinnoUgric system. So, it is worth considering. Even Diószegi showed that parallels of Hungarian táltoses (shamans) fighting like oxen can be found by Altai Turks but not by Finno-Ugrians.

When we will have completed the series of Uralic mythologies, we might have found out who resembles who. There are a number of similar elements; yet, Hungary is not part of the Finno-Ugric system. Not that I want to deny something, but there are plenty of things that have to be surveyed and analysed.

Finally, could you please tell us what kind of relationships you have with Estonian folkloristics and ethnography?

Estonian folkloristics is very close to my heart. Several of my works have been published in Estonian and I have received good feedback. I think that I and my Estonian colleagues have come to understand each other.

Thank you for sharing your thoughts about your life and work with us! 